Extent of air pollution in Kandy area, Sri Lanka: Morphological, mineralogical and chemical characterization of dust

D.S. Samaradiwakara and H.M.T.G.A. Pitawala*

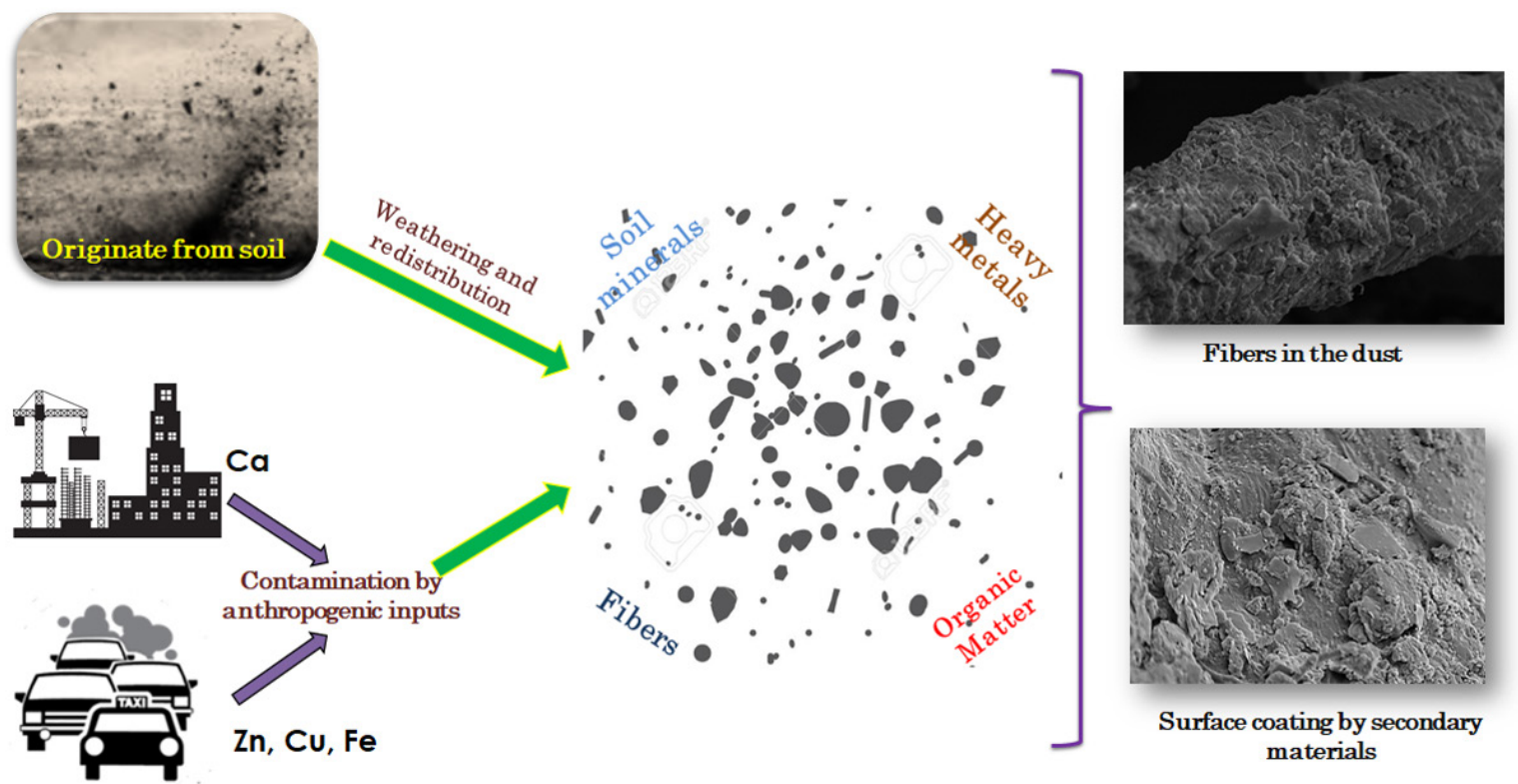

Highlights

- Chemistry, mineralogy and morphology of natural dust are altered due to the anthropogenic influences. 
RESEARCH ARTICLE

\title{
Extent of air pollution in Kandy area, Sri Lanka: Morphological, mineralogical and chemical characterization of dust
}

\author{
D.S. Samaradiwakara ${ }^{1,2}$ and H.M.T.G.A. Pitawala ${ }^{1,2^{*}}$ \\ ${ }^{1}$ Postgraduate Institute of Science, University of Peradeniya, Peradeniya, Sri Lanka. \\ ${ }^{2}$ Department of Geology, Faculty of Science, University of Peradeniya, Peradeniya, Sri Lanka.
}

Received: 04/12/2020; Accepted: 01/09/2021

\begin{abstract}
Dust is one of the most common sources of air pollution in cities, providing a considerable health risk. Kandy, Sri Lanka, has been declared as a UNESCO World Heritage Site. As a result, a study into causes of air pollution in Kandy and its environs is urgently required. We examined the composition of dust particles collected from the city and suburbs to determine the degree of particulate pollution. The abundance of particles and materials in various phases has previously been quantified in one dimension in an idealized sphere. The morphological examination of particulate matter is usually ignored. Eighteen road and thirteen household dust samples collected in the Kandy Municipal area were analyzed for elemental concentrations, as well as for mineralogical and morphological characteristics. Higher $\mathrm{Ca}, \mathrm{Zn}$, and $\mathrm{Cu}$ concentrations in the samples indicate anthropogenic (construction industry and traffic activities) influences on the dust. Mineralogically, fine and coarse dust fractions are dominated by clay minerals and quartz with feldspar. The majority of fibrous materials in dust are coated with secondary matter, resulting in short suspension duration in the atmosphere and, as a result, a reduction in the harmfulness of the fibers. In terms of mineralogy, morphology, and chemical properties, road and household dust samples are nearly identical. Despite the fact that dust is primarily derived from soil, its composition has been altered due to anthropogenic influences such as transportation and construction activities. As a result, dust containing clay particles can be regarded of as a fluxing and heavy metal accumulation medium. Although fibers have minor influence on human health and the environment, heavy metals have a significant impact. Though industrial and transportation activities in Kandy are remarkably low when compared to those in other major cities in Sri Lanka and megacities around the world, pollution levels in the city are comparably high. To reduce the vulnerability of the current pollution condition of the city, appropriate, long-term strategies for construction and transportation activities are required.
\end{abstract}

Keywords: Kandy; dust; heavy metals; fibers; urban environment.

\section{INTRODUCTION}

Dust is one of the most common air pollutants, derived from the interaction of solid, liquid, and gaseous materials produced by both natural and artificial processes (Banerjee, 2003). The decline of air quality in urban areas around the world has been one of the key challenges in recent decades.
As air quality deteriorates, many emerging countries face several environmental issues (Bhaskar and Mehta, 2010). Dust contributes significantly to fine particulate matter (PM) emissions (Wang et al., 2005; Wang et al., 2011).

Dust is a heterogeneous mixture of organic, inorganic, and biological particles that come from a variety of places. Natural sources of dust include weathering, erosion, and redistribution of adjacent soil, seawater spray, atmospheric wet and dry deposition, and natural rock dust. Transportation-related activities such as vehicular emissions and abrasion-induced wear of tires, brake pads, and other vehicle parts, as well as industrial and domestic activities, are the anthropogenic sources of dust (Chang et al., 2009; Bhaskar and Mehta, 2010; Gupta, 2020). Coal and other fossil fuel-fired power stations, mining activities, the cement and lime industries, and construction activities all contribute to the secondary dust particle formation process.

After being released into the environment, dust particles may stay in the air for some time before settling and accumulating on surfaces. The morphological characteristics of dust particles, such as size, shape and aerodynamic diameter; environmental factors, such as climate, wind speed and direction; and anthropogenic factors, such as land use patterns and vegetation cover, all influence dust distribution and behaviour in the atmosphere (Kim et al., 1998; McDonald and Biswas, 2004; Pereira et al., 2007; Pey et al., 2008).

As a result of rapid development in the last few decades, human activities that lead to changes in dust distribution in urban areas have resulted in substantial land use degradation in developing countries (Kim et al., 2013). Dust poses a serious threat to the health of the urban population (Bosco et al., 2005). In consideration of the health effects of dust, there are no safe threshold limits below which the health effects do not occur (WHO, 2017). After entering the body, both coarse and fine particles produce health impacts, further, finer particles are more hazardous since they can penetrate deep into the lung tissues. (De Costa, 2008; Wang et al., 2016; Gope et al., 2017). Dust pollution has been linked to an 
increase in chronic obstructive pulmonary disease, asthma, pneumonia, cardio-respiratory disease and respiratoryrelated disorders. (Balachandran et al., 2000; Pope and Dockery, 2006; Brunekreef et al., 2009; Boldo et al., 2011).

Emission sources, atmospheric chemical processes, and climatic variables all have a role in dust generation and distribution (Harrison, 2006; Garland et al., 2008). Due to its complexity, dust can cause a number of chemical reactions that result in secondary compounds (Chen et al., 2006). Other contaminants can be carried by dust particles and physiochemical properties such as the nature, size, and surface roughness of various minerals and organic compounds determine their pollutant capability (McBride, 1994; Butte and Heinzow, 2002). Anthropogenic particles can also combine with mineral components to form unique combinations, which impact the distribution and behaviour of dust.

Due to differences in mineral solubility, lead in galena $(\mathrm{PbS})$ is less accessible than lead in carbonate $\left(\mathrm{PbCO}_{3}\right)$ (Casteel et al., 2006). The morphology of dust particles can be utilized to characterize behaviour, identify sources, creation mechanisms, climatic conditions, travel distance from the source and their potential health consequences (Ličbinský et al., 2010).

The majority of urban environments of Sri Lanka are densely populated areas with significant levels of anthropogenic activity. The dispersal of dust is more affected by unplanned land use patterns and significant traffic congestion in cities. UNESCO has designated Kandy as a World Heritage City. As a result, it is essential to analyze the mode of air pollution in Kandy and its environs. In comparison to other cities in the country, it features unique urban and climatological surroundings.

The wind flow and circulation, in particular, differ from those in other major Sri Lankan cities (Pitawala et al., 2013). The basin-like and bottleneck geomorphology of the city operate as obstacles to wind flow, which prefers to cycle within the metropolitan area. This may result in an increase in the gathering of air pollutants such as dust particles and heavy metals, which may stay in the air for prolonged periods of time due to a lack of space to blow them out, finally settling in the urban region (Abeyratne and Ileperuma, 2006; Weerasundara et al., 2017). Despite the fact that Kandy has a unique environment in comparison to other cities, only a few studies on dust have been conducted (Pitawala et al., 2013; Weerasundara et al., 2017).

The morphologic evaluation of particulate matter is often neglected, despite the importance of dust morphology. This study is a new approach to understanding air pollution in the urban environment of Kandy city. Hence, a comprehensive characterization based on mineralogy and morphology of dust along with chemical studies has been carried out to get a better understanding of the possible sources, distribution patterns and levels of the urban dust. It would also be useful to introduce appropriate pollution prevention methods for the long-term development of urban ecosystems. Therefore, the major objective of the present study was to understand the factors influencing the accumulation and distribution patterns of the urban dust, based on the mineralogical, morphological and chemical characteristics.

\section{MATERIALS AND METHODS}

\section{Study area}

The city of Kandy is the second most commercially important city in Sri Lanka, extending over an area of $26 \mathrm{~km}^{2}$ with an urban population higher than 100,000 (Census, 2012). Kandy lies at an elevation of $500 \mathrm{~m}$ from mean sea level and belongs to the tropical rainforest climate. The study area has an average annual rainfall of nearly $1500 \mathrm{~mm}$ with an average annual temperature of $24.5^{\circ} \mathrm{C}$. The average annual percentage of humidity is $84.0 \%$. The wind direction and speed are primarily controlled by the monsoonal conditions (Department of Meteorology, 2017). However, the wind circulation in the city is high as it is located in an area that shows a basin-like morphology which act as a barrier to the movement of the wind (Weerasundara et al., 2017; Dissanayake et al., 2019). Precambrian metamorphic rocks are underlying the setting of the Kandy and it is located in the Highland Complex (HC) of Sri Lanka. The major bedrock types found within the area comprise biotite and hornblende bearing gneisses, charnockitic and granitic gneisses as well as calcsilicate gneiss (Cooray, 1994; Kehelpannala, 2003).

Around 350,000 people are entering to the city in a daily basis, comprising about 90,000 for employment and over 60,000 for schools. The total vehicle entry level to city has increased to 56,000 vehicles per day and has a growth rate of 5\% per annum (Kandy City Transport Study, 2011). As the city is located in a narrow valley, higher traffic congestion in the city is observed with high quantity of vehicles travelling within a small area at a very low speed. And also, buses are racing on first gear, stopping at all bus stops for a long time (Premasiri et al., 2012).

\section{Sample collection}

A total of 31 dust samples were collected including 18 road dust $(\mathrm{R})$ and 13 household dust samples. Sampling was done in 2019 during the dry period as the rain fall results in wash-off process which could lead redistribution and removal of the available road dust in the surfaces (Egodawaththa et al., 2007). Road dust samples were collected within the center of the city and in the surrounding commercial areas with high traffic intensities where traffic lights are in the vicinity. Road dust samples were collected by sweeping the road surface using a plastic brush and a dustpan and collecting the dust into sealed polythene sample bags. Household dust samples were collected from selected residential neighborhoods of the Kandy urban area. These areas had higher elevations and lower traffic conditions as compared to the areas where road dust samples were collected. Dust gathered on window panels and top of other furniture in abandoned houses was also collected following the same procedure used to collect road dust samples. The dustpan and plastic brush were washed 
using methanol after collection of dust at each location to minimize contaminations.

\section{Chemical, mineralogical and morphological analysis}

A portion of dust were first weighted and treated with 70\% hydrogen peroxide $\left(\mathrm{H}_{2} \mathrm{O}_{2}\right)$ for removal of the organic matter and set aside until the bubbling was over. When there were no more bubbling, the samples were washed by water and oven dried for $24 \mathrm{~h}$ in $105^{\circ} \mathrm{C}$. The samples were weighted and the difference in the weight was taken as the organic matter content. Organic matter contents were calculated as weight percentage of the initial dry weight.

Approximately $0.2 \mathrm{~g}$ of each sample was accurately weighed and digested for heavy metal analysis using aqua regia $\left[3: 1 \mathrm{HCl}(34 \%) / \mathrm{HNO}_{3}(69 \%), \mathrm{v} / \mathrm{v}\right]$. The extracts were analyzed by flame atomic absorption spectrophotometry (AAS-Perkin Elmer, Model 2380) to determine the total concentrations of $\mathrm{Zn}, \mathrm{Cu}, \mathrm{Ni}, \mathrm{Fe}, \mathrm{Mn}, \mathrm{Pb}, \mathrm{Na}, \mathrm{K}, \mathrm{Ca}$ and $\mathrm{Mg}$. Calibration control standards were used for the linear calibration.

Table 1: Detection limits of the heavy metals in AAS.

\begin{tabular}{cc}
\hline Element & Detection Limit $\left(\mathbf{m g ~ L}^{-1}\right)$ \\
\hline $\mathrm{Pb}$ & 0.029 \\
$\mathrm{Cu}$ & 0.004 \\
$\mathrm{Mn}$ & 0.011 \\
$\mathrm{Zn}$ & 0.002 \\
$\mathrm{Ni}$ & 0.004 \\
\hline
\end{tabular}

Mineralogy of the samples was studied under an optical reflection microscope (Nikon) at the Mineralogy Laboratory, Department of Geology, University of Peradeniya. Magnetic material was separated using a handmagnet. The magnetic material content was calculated as a percentage.

Scanning Electron Microscope (SEM), model Zeiss EVO LS 15 was used to study the size variations, sorting of particles, shapes of the particles, surface features and to detect the presence of fibers. In the sample preparation for the SEM analysis, samples were placed on carbon plaster to coat with $20 \mathrm{~nm}$ thin layer of gold ( $\mathrm{Au}$ ) and palladium (Pd). The Energy Dispersive X-ray spectroscopy (EDX) which was equipped with the SEM was used in the study of the elemental composition of the appropriate fibers and magnetic grains and grain surfaces.

\section{Assessment of the heavy metals}

\section{Enrichment Factor (EF)}

The following equation was used to calculate the EF of the heavy metals (Kantor et al., 2018).

$$
E F=[x / \mathrm{Fe}] \text { Sample } /[x / \mathrm{Fe}] \mathrm{Upper} \text { Continental Crust (UCC) }
$$

where, $x$ is the concentration of the element. In the present study, iron ( $\mathrm{Fe})$ was used as the normalizing element, since Fe has a relatively high natural concentration, and further, it is not expected to be substantially enriched from the anthropogenic process and sources (Abrahim and Parker, 2008). UCC values of elements were obtained from Rudnick and Gao (2005) for the comparison. The following classification from Barbieri et al. (2015) is given for the EF (Table 1).

Table 2: EF categories (Barbieri et al., 2015).

\begin{tabular}{cc}
\hline Value & Soil dust quality \\
\hline $\mathrm{EF}<2$ & Deficient to minimal enrichment \\
$2<\mathrm{EF}<5$ & Moderate enrichment \\
$5<\mathrm{EF}<20$ & Significant enrichment \\
$20<\mathrm{EF}<40$ & Very high enrichment \\
$\mathrm{EF}>40$ & Extremely high enrichment \\
\hline
\end{tabular}

\section{RESULTS AND DISCUSSION}

\section{Organic matter content}

Higher organic matter contents in road dust were mainly found in samples collected near road junctions, areas of high traffic intensity and areas around traffic lights (Figure 1). Wind is the main natural factor of the transportation of dust particles and consequently, road junctions act as a barrier to smooth wind flow. Therefore, dust that transport with wind tends to deposit in the vicinity of the junction. Vehicle movement is one of the main factors that contribute the production of road dust. The shearing action between the tyre and the road surface creates loose materials that are then transported into the air by the turbulence caused by the movement of vehicles. Vehicles are subjected to constant starting and stopping with breaks in locations with high traffic intensities or traffic signals, resulting in increased shearing activity and intensive dust particle formation. The organic materials in the dust produced by such actions are concentrated with tyre materials, road particles such as bitumen and soil organic matter. The turbulence created by movement of vehicles would not be adequate to lift and transport the generated coarse dust particles since the momentum of vehicles is minimal. Thus, the organic stuff in road dust formed by shearing will be deposited in situ. Organic materials made up of functional groups, such as COO-, would create complexes with heavy metals that are more bioavailable than the metal itself (Alloway, 1995). The organic matter content of road dust in the study area (Table 2) is higher than that of road dust in the Colombo metropolitan area (CMA), Sri Lanka (Herath et al., 2015), Delhi, India (Shandilya et al., 2013), West Midlands, United Kingdom (Shilton et al., 2005) and Manchester, England (Robertson et al., 2003).

\section{Magnetic material content}

Samples with high concentrations of magnetic material were typically found in samples obtained from major highways with heavy traffic congestion (Figure 2). This suggests that there is a correlation between magnetic material abundance and traffic congestion (Spassov et al., 2004). The sample location closest to the railway station 


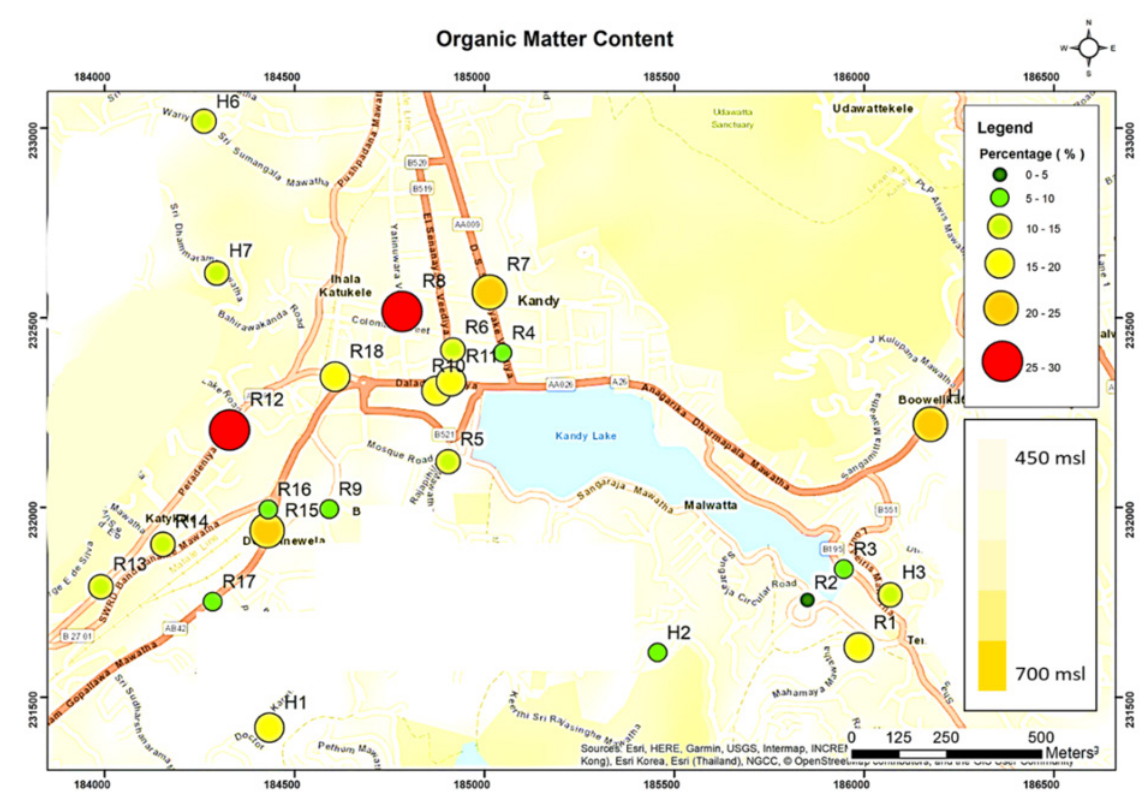

Figure 1: Map showing the distribution of organic materials in the study area.

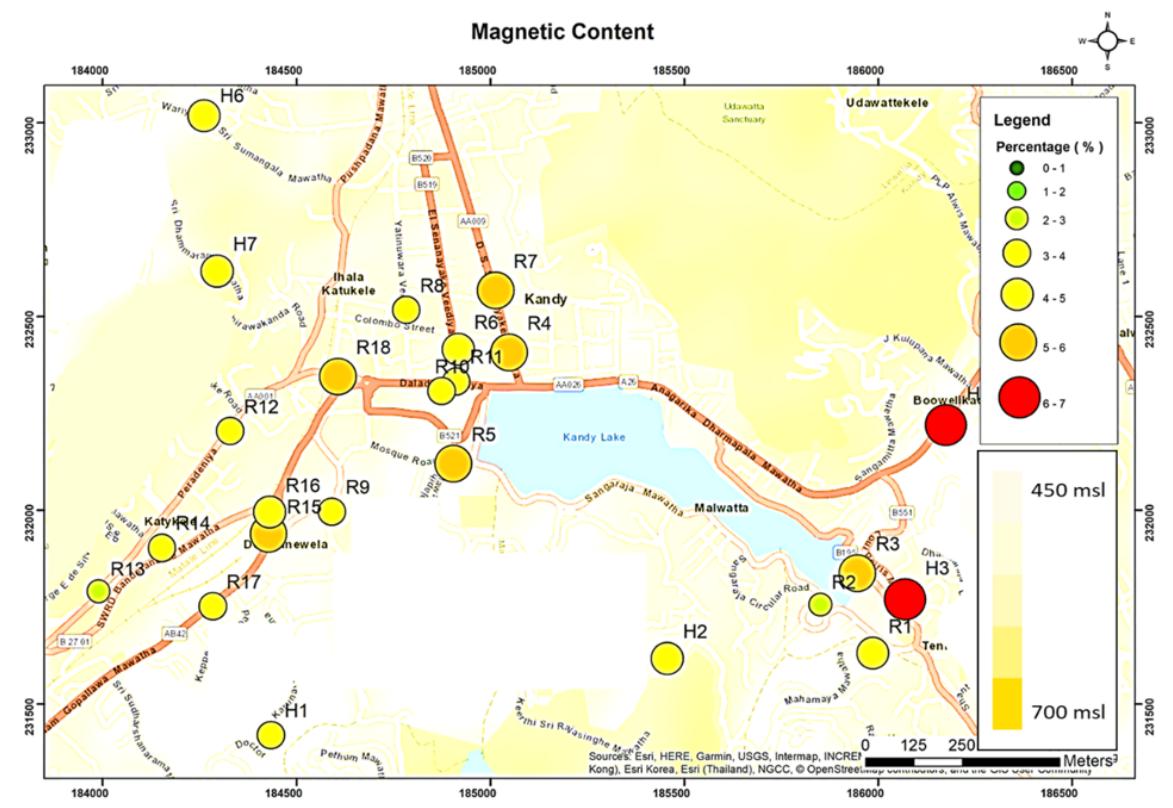

Figure 2: Map showing the distribution of magnetic materials in the study area.

has higher concentrations of magnetic materials. High magnetic material concentration samples were typically found in those obtained from main highways with heavy traffic congestion (Figure 2). This indicates that there is a relationship between magnetic material abundance and traffic congestion (Spassov et al., 2004). The sample location closer to the railway station has higher concentration of magnetic material. According to Moreno et al. (2015) the high value obtained in this area is mostly attributable to the creation of magnetic material in the abrasion of sliding and wear at the brake-rail wheel and rail wheel-rail interfaces. The high turbulence caused by train movement is mainly responsible for particle transport. Corrosion of trains that have been stationary for a long time may also result in high concentrations of magnetic material.

\section{Chemical characteristics}

Calcium (Ca), followed by $\mathrm{Fe}$, is the most abundant element in both road and domestic dust samples. In both types of samples, the heavy metal concentrations are in the following order: $\mathrm{Zn}>\mathrm{Mn}>\mathrm{Cu}>\mathrm{Ni}>\mathrm{Pb}$. Except for $\mathrm{Cu}$, all heavy metals are higher in road dust than in residential dust (Table 3). In both road and residential dust, key element concentrations change in the order $\mathrm{Ca}>\mathrm{Fe}>\mathrm{Mg}>\mathrm{K}>\mathrm{Na}$. Iron $(\mathrm{Fe}), \mathrm{Cu}$ and $\mathrm{Zn}$ concentrations are higher in residential dust than in road dust.

Despite the low concentrations of $\mathrm{Na}, \mathrm{Mg}, \mathrm{K}$ and $\mathrm{Mn}$ (Table 3 ), they are comparable with the background values, and can be considered as derived from natural processes. The concentrations of these metals are low due to the mixing 
of other materials derived from anthropogenic sources. Even though $\mathrm{Fe}$ is found in low concentrations compared to the background levels, high anthropogenic influence can be attributed to the presence of magnetic materials in the dust. However, Ca shows higher enrichment with respect to the background levels (Table 3). The presence of high $\mathrm{Ca}$ concentrations may be due to the construction process, as destruction of existing structures can release enormous amounts of dust into the environment (Guttikunda and Goel, 2013).

Zinc ( $\mathrm{Zn}), \mathrm{Cu}, \mathrm{Ni}$ and $\mathrm{Pb}$ can be considered as anthropogenically derived metals as they have much higher measured concentrations compared to the background values (Table 3). There must be anthropogenic inputs of these metals to possess such higher levels of concentrations in the road and household dust. It indicates that chemical composition of the naturally derived dust has been altered due to the anthropogenic influence.

The present study reveals that Kandy has higher concentrations of $\mathrm{Zn}, \mathrm{Cu}, \mathrm{Fe}$ and $\mathrm{Mn}$ (Table 4). The elements, $\mathrm{Zn}$ and $\mathrm{Cu}$, in road dust could be derived mostly by vehicular emissions (Charlesworth and Lees, 1998; Al-Khashman, 2007). Even though Colombo and other megacities in the world have significantly higher traffic activities, industries, construction activities and population density, concentrations of $\mathrm{Zn}, \mathrm{Pb}$ and $\mathrm{Cu}$ in dust are comparably lower than those of Kandy city (Table 4 and 5). The atmospheric deposition shows comparable values with the

Table 3: Organic matter and magnetic material contents in the road and household dust.

\begin{tabular}{ccccccc}
\hline \multirow{2}{*}{ Sample type } & \multicolumn{3}{c}{ Organic matter content } & \multicolumn{2}{c}{ Magnetic material content } \\
\cline { 2 - 6 } & Maximum & Minimum & Mean & Maximum & Minimum & Mean \\
\hline Road dust & $29.06 \%$ & $4.63 \%$ & $15.04 \%$ & $5.89 \%$ & $2.41 \%$ & $4.25 \%$ \\
Household dust & $21.60 \%$ & $8.26 \%$ & $15.50 \%$ & $6.75 \%$ & $3.48 \%$ & $4.79 \%$ \\
\hline
\end{tabular}

Table 4: Concentrations of major and heavy metals $(\mathrm{mg} / \mathrm{kg})$ of samples studied.

\begin{tabular}{cccccc}
\hline \multirow{2}{*}{ Major metals } & \multicolumn{2}{c}{ Road dust } & \multicolumn{2}{c}{ Household dust } & \multirow{2}{*}{ Background } \\
\cline { 2 - 4 } & Range & Average & Range & Average & \\
\hline $\mathrm{Mg}$ & $5,160-12,182$ & 8,909 & $6,876-11,301$ & 8,547 & 11,000 \\
$\mathrm{Na}$ & $772-2,213$ & 1,202 & $428-1,962$ & 1,140 & 26,500 \\
$\mathrm{~K}$ & $1,323-6,032$ & 3,113 & $2,501-6,035$ & 4,364 & 13,000 \\
$\mathrm{Fe}$ & $27,772-50,074$ & 36,704 & $29,991-63,052$ & 40,347 & 86,000 \\
$\mathrm{Ca}$ & $20,879-127,596$ & 50,706 & $22,768-107,949$ & 45,164 & 27,200 \\
Heavy metals & & & & 40 & 25 \\
$\mathrm{~Pb}$ & $15-126$ & 49 & $22-72$ & 352 & 800 \\
$\mathrm{Cu}$ & $235-447$ & 319 & $299-409$ & 507 & 68 \\
$\mathrm{Mn}$ & $403-724$ & 541 & $451-578$ & 783 & 50 \\
$\mathrm{Zn}$ & $236-1,557$ & 775 & $406-3065$ & 300 & 8 \\
$\mathrm{Ni}$ & $252-364$ & 305 & $245-330$ & & \\
\hline
\end{tabular}

Table 5: Comparison of mean concentrations $\left(\mathrm{mg} \mathrm{kg}^{-1}\right)$ of heavy metals in dust in different cities in Sri Lanka.

\begin{tabular}{cccccccc}
\hline Study & Area & Type & $\mathbf{Z n}$ & $\mathbf{C u}$ & $\mathbf{P b}$ & $\mathbf{F e}$ & $\mathbf{M n}$ \\
\hline \multirow{2}{*}{ Pitawala et al., 2013 } & Colombo & Household & 18.1 & 2 & 2.3 & 32000 & 191 \\
\cline { 2 - 7 } & Kandy & Household & 738.9 & 29.8 & 3.5 & 39000 & 145.9 \\
\hline Herath et al., 2015 & Colombo & Road & 476 & 174 & 71 & 29268 & 689 \\
\hline Priyadarhana et al., 2015 & $\begin{array}{c}\text { Colombo } \\
\text { suburbs }\end{array}$ & Road & 284.01 & 101.86 & 34.39 & NA & NA \\
\hline $\begin{array}{c}\text { Weerasundara } \text { et al., } \\
\text { 2018 }\end{array}$ & Kandy & $\begin{array}{c}\text { Atmospheric } \\
\text { deposition }\end{array}$ & 1116.9 & 123.6 & 234.4 & 13774.9 & 273.6 \\
\hline This study & Kandy & Road & 775 & 319 & 49 & 36704 & 541 \\
\cline { 2 - 7 } & Kandy & Household & 1113 & 352 & 40 & 40347 & 507 \\
\hline
\end{tabular}


dust samples, proving atmospheric deposition contribution to the presence of heavy metals of dust in the study area (Table 4). It also proves that the suspended particles only disperse over the urban area and deposit within the city itself due to the basin-like geomorphology of the area. However, the suspended dust particles in the Colombo city may disperse over a large area and reduce the concentration of accumulation with the wind flow and the higher wind velocities due to its geographical location near the coast (Pitawala et al., 2013).

\section{Sources of heavy metals}

As $\mathrm{Zn}$ is used as a vulcanization agent in vehicle tyres (Alloway, 1990), the higher wearing rate and corrosion rates in high-temperature tropical areas, such as Kandy, may contribute to the high $\mathrm{Zn}$ content in the dust ( $\mathrm{Li}$ et al., 2001). Furthermore, due to the morphological conditions of the study area, the sharp bends and steep slopes of roads may exacerbate tire wear (Pitawala et al., 2013). Usage of $\mathrm{Zn}$ in alloys, parchment papers, glass, dry cell batteries and electrical apparatus may also contribute to the higher content of $\mathrm{Zn}$ in household dust (Adriano, 1986). Moreover, food wastages containing higher levels of $\mathrm{Zn}$ would contribute to higher levels of $\mathrm{Zn}$ in the dust.

The sources of copper $(\mathrm{Cu})$ in the road dust could be corrosion of metallic parts of cars derived from engine wear, thrust bearing, brushing and bearing metals (AlKhashman, 2007). Contamination of $\mathrm{Cu}$ in the household dust is influenced by the general condition of the house such as, distance from the road, level of traffic and cleaning habits (Ibanez et al., 2010). The main source of $\mathrm{Pb}$ could be pigments present in paints. The white and the yellow lines marked on the road using paint are subjected to intense alteration of conditions in the study area due to the tropical climate. In addition, vehicles tend to cross white lines with higher friction in sharply curved bends may cause higher $\mathrm{Pb}$ value in the area. Another potential source of $\mathrm{Pb}$ pollution in the environmental samples including dust is the combustion of gasoline that contains tetraethyl lead as an anti-knock agent (Tuzen, 2003). Although leaded gasoline is not being used, at present, in Sri Lanka, Pb released when it was used earlier is still in the sediments and is circulated within the Kandy area because of its basin-like morphology. Also, the $\mathrm{Pb}$ levels may have been influenced by the usage of lead-based paints which consist of lead chromate (yellow pigments) and other $\mathrm{Pb}$ pigments. Further, Ni pollution on local scale is caused by emissions from vehicle engines that use nickel gasoline and by the abrasion and corrosion of $\mathrm{Ni}$ from vehicle parts (Al-Kashman, 2007).

\section{Assessment of heavy metal levels}

When considering at the overall distribution of heavy metals, samples collected from heavily trafficked places (R4, R8, R11 and H4), the main bus station (R14), train station (R15) and an abandoned construction site (H3) indicate higher values of all heavy metals (Figure 3 ).

EF (enrichment factor) values, which are used to evaluate anthropogenic input and pollution degree, reflect the degree of heavy metal pollution in an area (Yang et al., 2016). Higher EF values of all the heavy metals were identified in R7, R8, R11, R14, R15, R18, H3 and H4 sample locations (Figure 4). These locations are in places with high traffic congestions. Heavy metals, which have EF $>10$, were always believed to derive from human activities (Yang et al., 2016).

Highly significant Pearson correlation values ( $>0.6$ ) were found between $\mathrm{Cu}$ and $\mathrm{Zn}, \mathrm{Cu}$ and $\mathrm{Pb}, \mathrm{Pb}$ and $\mathrm{Ni}$, and, $\mathrm{Zn}$ and $\mathrm{Pb}$. All these correlations between sample locations and between heavy metals show that the origin of the metals in the investigated area is highly related to the transport activities.

\section{Mineralogical characteristics}

Modal mineralogical analyses of coarse fraction of dust $(>75 \mu \mathrm{m})$ reveal that the samples are dominated by quartz $(36 \%)$ and opaque minerals (Figure 5). Minor amounts of calcite are also present, which may be either naturally derived or secondary products from construction materials. The fine fraction of the dust samples is dominated by clay minerals.

Mineralogy of the soils of the study area differs from the underlying bed rocks since the ferromagnesian minerals except mica have been subjected to intense weathering due to tropical climatic conditions (Pohl and Emmerman, 1991). Despite the presence of iron oxide minerals of the bed rocks as accessory minerals, their content in the dust is relatively high. It may be due to their resistance

Table 6: Comparison of mean concentrations $\left(\mathrm{mg} \mathrm{kg}^{-1}\right)$ of heavy metals in dust in mega cities of the world.

\begin{tabular}{ccccc}
\hline Study & City & Pb & Zn & Cu \\
\hline Wang et al., 1998 & London & 897 & 1866 & 300 \\
Nazzal et al., 2014 & Toronto & 182.8 & 232.8 & 162.2 \\
Chattopadhyay et al., 1999 & Sydney & 389 & 657 & 147 \\
Suryavanshi et al., 2016 & Delhi & 120 & 284 & 191 \\
Kim et al., 1998 & Taejon & 52 & 214 & 57 \\
This study & Kandy & 49 & 775 & 319 \\
\hline
\end{tabular}


to weathering. However, some iron fragments from the metallic materials also appeared as iron oxide minerals.

There is no significant difference in the mineralogical composition between the two different dust samples (Figure 5). This indicates that the factors including geographical location, land use, nature of traffic and antecedent during the dry period affect the composition of dust particles (Amato et al., 2011). However, the mineral composition of the dust samples does not depend on their location.
Anthropogenic influence on the percentage of the mineral and other inorganic solids in both types of samples is not considerable, and both types of samples may have derived from soil of the basement of the area (Xie et al., 2000). The modal percentage of the minerals of the samples is in the range of $70 \%$ to $85 \%$ and they are common rock forming minerals of the study area. Most of these particles are covered by fine dust particles rich in organic matter that have been released from anthropogenic sources. Poor sorting, high degree of angularity in the particles, presence
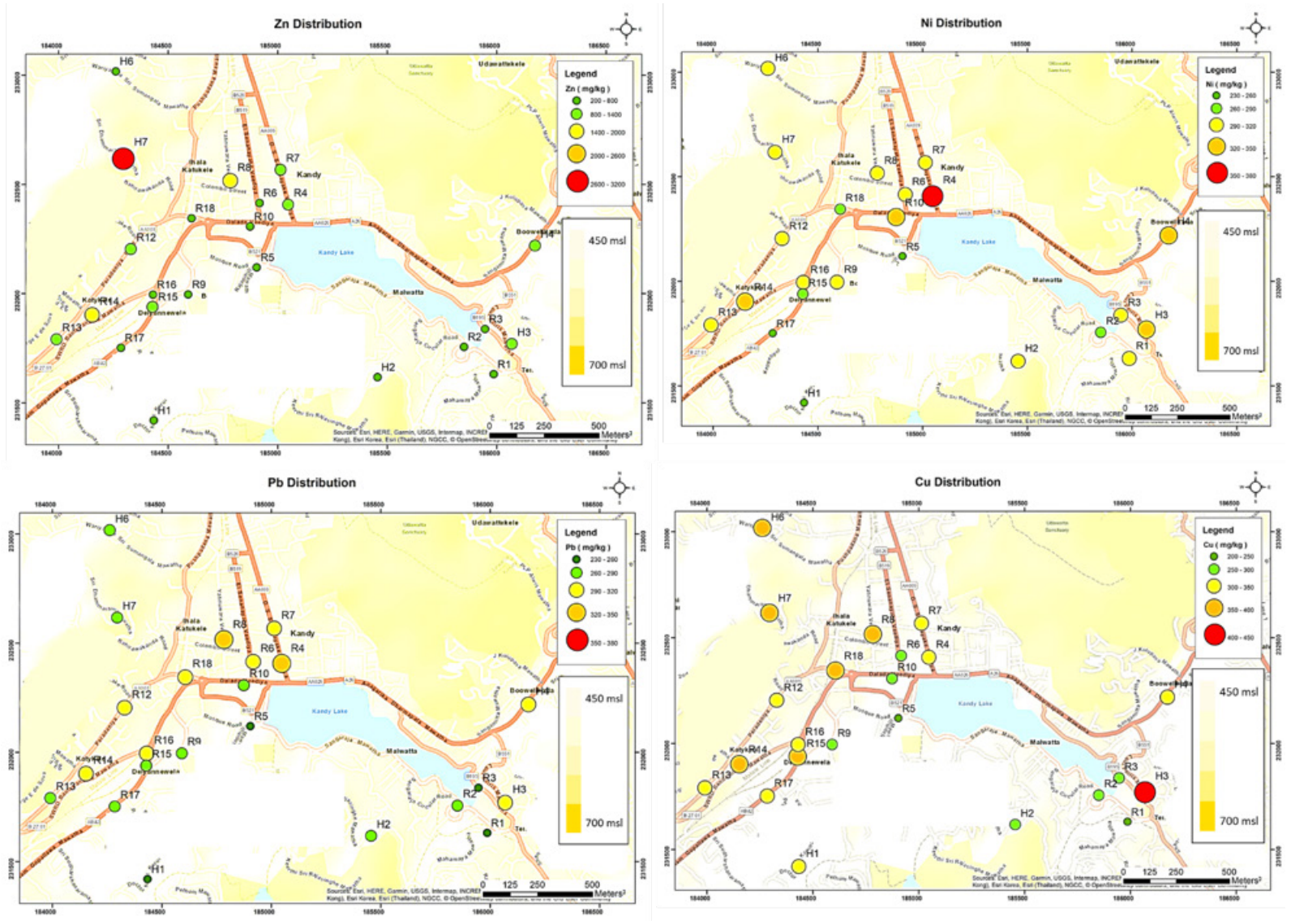

Figure 3: Maps showing the distribution of heavy metals $(\mathrm{Zn}, \mathrm{Ni}, \mathrm{Pb}$ and $\mathrm{Cu})$ in the study area.

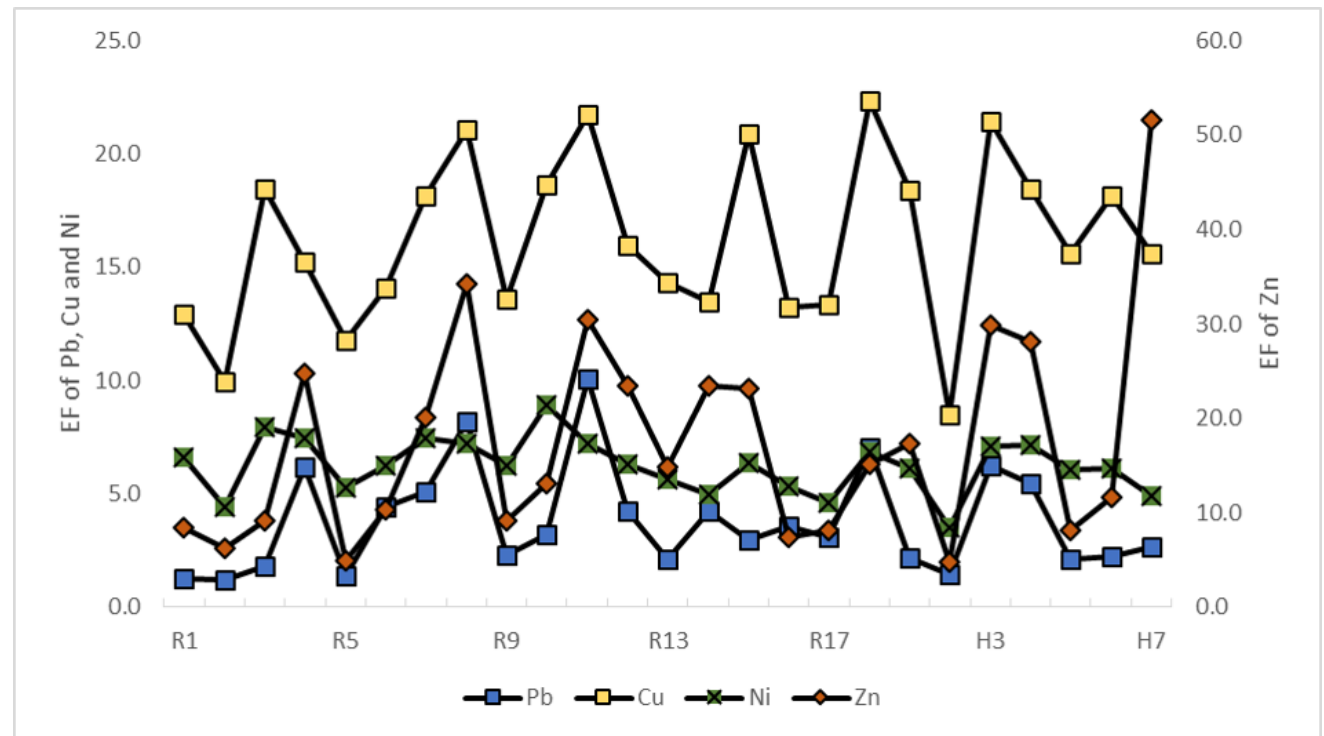

Figure 4: Variation of EFs of different heavy metals in the both road and household dust samples studied. 
A

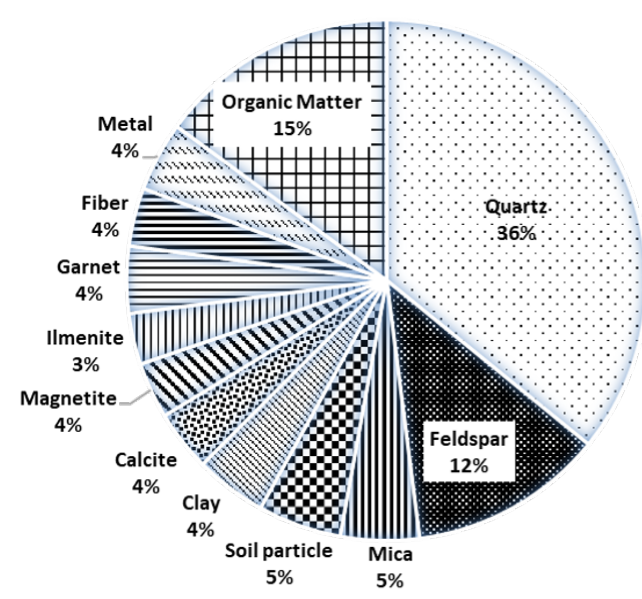

B

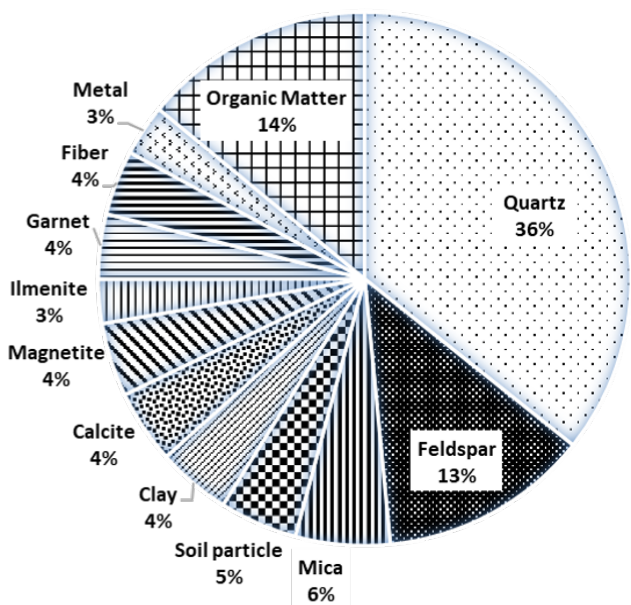

Figure 5: Average percentages of mineralogical and anthropogenic components of (A) road and (B) household dust samples.

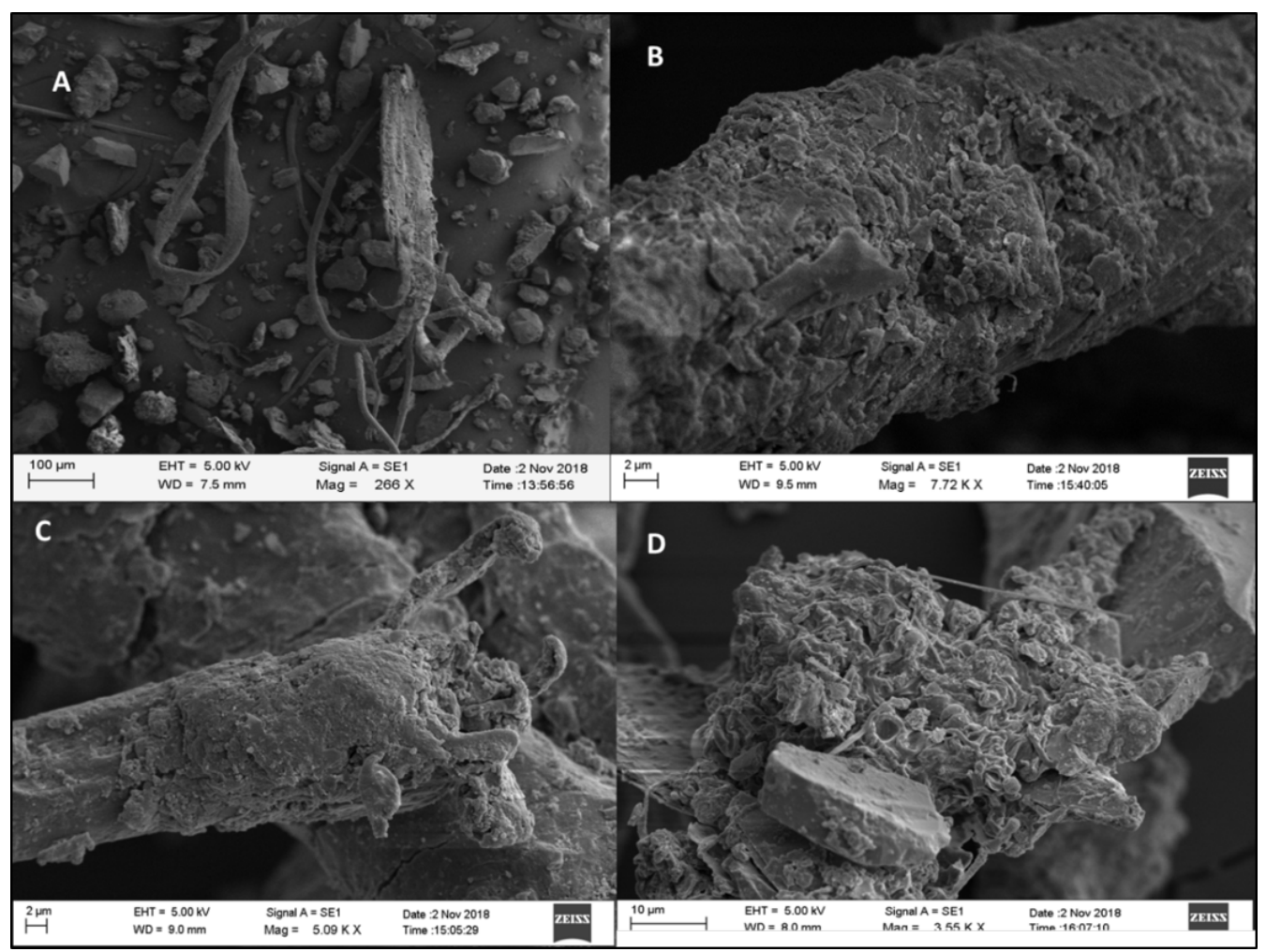

Figure 6: SEM image of (A) porous nature of the surface coating of the fibers in the road dust samples, (B) surface coated cloth fibers which the fibrous nature has been disappeared, (C) fracturing of the surface of a fiber in the sample, (D) the aggregate which contain the materials derived from biological materials; roots and pollen.

of fresh or slightly weathered feldspar and chlorite suggest that the dust samples have been transported for short distances.

\section{Morphological characteristics}

According to SEM investigations (Figure 6), dust particles are in a variety of sizes and shapes. The dust particles of all types of samples are covered by surface coatings (Figure 6A). As a result, the fibrous nature of some particles has been changed (Figure 6B). The surface coatings of the particles may have occurred due to the high atmospheric humidity that can increase adhesiveness of the particle surface due to the capillary effect (Kollensperger et al., 1999). Capillary water can retain in particles, and it will tend to attract and react with finer particles forming the surface coating. Fibers of household dust have lower surface coating, than those in road dust samples. It may be due to low capillary water in such type of dust. The SEM / EDX data showed the presence of high $\mathrm{C}$ and $\mathrm{O}$ in the fibrous materials and on the surface coating indicating the organic origin of the 
fibers. Irregular anhedral and subhedral mineral particles and clusters of particles (Figure 6D) may have originated from natural sources (Furutani et al., 2011) and the aggregates may have formed due to adhesive and cohesive nature of water. However, particles having smooth surfaces (e.g. mica) contain lower content of coating compared to those having rough surfaces. The reason for this may be the adhesion forces that are higher on rough surfaces than on flat surfaces (Shi et al., 2015). Naturally derived particles tend to have smooth surfaces, while particles derived from anthropogenic processes have a rough surface. Therefore, naturally derived particles have lower thickness of surface coating while anthropogenically derived particles have thick surface coating. Particle aggregates could be identified as the particles that were cemented together by cementing materials such as organic matter, calcite or salt (Meza-Figueroa et al., 2016). Some aggregates were bound together by fibrous grains. These aggregates were concentrated with fibers, mineral particles, anthropogenic particles and some particles with a biological origin (Figure 6D).

In addition to the porous nature of the surface of the particles (Figure 6A), breaking of the mineral grains were observed through their cleavage planes (Figure 6C). This indicates a low level of stress during the collision between grains, grains and roads and grains and vehicles. Further, the surfaces of fine grains have been subjected to abrasion. The surface coatings of the flat and smooth surface particles are lower than that of the rough surface particles.

\section{CONCLUSIONS}

Characterization of particles of both household and road dusts of the Kandy urban area indicates that both types do not differ much in terms of mineralogy, morphology and chemical composition. Concentrations of $\mathrm{Ca}, \mathrm{Cu}$ and $\mathrm{Zn}$ are significantly higher than the background levels. High concentrations of $\mathrm{Ca}$ indicate that construction activities of buildings contribute much to the chemical composition of dust. The particles in the atmosphere are deposited after short residence time and transportation due to the wind circulation of the urban area. The tendency for the suspension of fibrous materials gradually decreases due to the coating of finer particles observed on their surfaces.

Even though dust is primarily originated from soil, it had been altered by anthropogenic and natural processes, such as traffic emissions, construction processes, and wearing and weathering of man-made materials. Further, dust particles can be considered as a fluxing agent and storing sites of heavy metal, as they consist of considerable amount of clay minerals derived from the soil. Alteration processes, such as, incorporation of the heavy metals and formation of the surface coating turns the primary particles, into secondary particles.

Natural conditions, mainly the underlying geology and climatic conditions, have masked the anthropogenic influence on the chemical, mineralogical morphological characteristics of both road and household dust in the Kandy urban environment. Therefore, interpretation of the dust pollution processes in the area by human interaction is complicated.

In the development projects for Kandy, measures should be taken to reduce the traffic congestion within the city as well as the number of vehicles entering the city, to improve the quality of life in urban population and city dwellers, and to build a sustainable city.

\section{RECOMMENDATION}

Plastics and microplastics were identified to be the most common sources of fibrous materials in the dust studied. Future research on microplastics in dust should be conducted to gain a better understanding of the current state of air pollution and its impact on human health.

\section{ACKNOWLEDGEMENT}

The authors are grateful for the financial support from National Research Council (grant no. NRC AB 19-004) under the under the funds of Ministry Industry and Trade, Russia.

\section{DECLARATION OF CONFLICT OF INTEREST}

The authors declare no conflicts of interest in preparing this article.

\section{REFERENCES}

Abeyratne, V.D.K. and Ileperuma, O.A. (2006). Air pollution monitoring in the city of Kandy: possible transboundary effects. Journal of the National Science Foundation of Sri Lanka 34(3): 137. DOI: https://doi. org/10.4038/jnsfsr.v34i3.3644.

Abrahim, G.M.S. and Parker, R.J. (2008). Assessment of heavy metal enrichment factors and the degree of contamination in marine sediments from Tamaki Estuary, Auckland, New Zealand. Environmental Monitoring and Assessment 136(1 - 3): 227 - 238.

Adriano, D.C. (1986). Other trace elements. In: Trace Elements in the Terrestrial Environments, Springer, New York Pp. 470-50.

Adriano, D.C. (2001). Trace Element in the terrestrial environments: biogeochemistry. bioavailability and risks of metal. $2^{\text {nd }}$ Springer-verlag, New York, Berlin, Heidelberg, Pp. 223 - 232.

Al-Khashman, O.A. (2007). The investigation of metal concentrations in street dust samples in Aqaba city, Jordan. Environmental Geochemistry and Health 29(3): $197-207$.

Alloway, B.J. (1990). Heavy Metals in Soils. Blackie, London.

Bellinger, D., Leviton, A. and Slowman, J. (1990). Antecedents and correlates of improved cognitive performance in children exposed in utero to low levels of lead. Environmental Health Perspectives 89: 5 - 11. DOI: https://doi.org/10.1289/ehp.90895.

Amato, F., Pandolfi, M., Moreno, T., Furger, M., Pey, J., Alastuey, A. and Querol, X. (2011). Sources and variability of inhalable road dust particles in three European cities. Atmospheric Environment 45(37): $6777-6787$. 
Balachandran, S., Meena, B.R. and Khillar, P.S. (2000). Particle size distribution and its elemental composition in the ambient air of Delhi. Environment International 26(1 - 2): 49 - 54.

Banerjee, A.D.K. (2003). Heavy metal levels and solid phase speciation in street dusts of Delhi, India. Environmental Pollution 123(1): 95 - 105. DOI: https:// doi.org/10.1016/S0269-7491(02)00337-8.

Barbieri, M. (2016). The importance of enrichment factor (EF) and geo accumulation index (Igeo) to evaluate the soil contamination. Journal of Geology and Geophysics 5(237): 2.

Bhaskar, B.V. and Mehta, V.M. (2010). Atmospheric particulate pollutants and their relationship with meteorology in Ahmedabad. Aerosol and Air Quality Research 10(4): 301 - 315. DOI: https://doi.org/10.4209/ aaqr.2009.10.0069.

Boldo, E., Medina, S., Le Tertre, A., Hurley, F., Mücke, H.G., Ballester, F. and Aguilera, I. (2006). Apheis: health impact assessment of long-term exposure to PM 2.5 in 23 European cities. European Journal of Epidemiology 21(6): 449 - 458.

Bosco, M.L., Varrica, D. and Dongarrà, G. (2005). Case study: inorganic pollutants associated with particulate matter from an area near a petrochemical plant. Environmental Research 99(1): 18 - 30. DOI: https:// doi.org/10.1016/j.envres.2004.09.011.

Brunekreef, B., Beelen, R.M.J., Hoek, G., Schouten, L.J., Bausch-Goldbohm, S., Fischer, P. and Jerrett, M. (2009). Effects of long-term exposure to traffic-related air pollution on respiratory and cardiovascular mortality in the Netherlands: the NLCS-AIR study. Research Report (Health Effects Institute) (139): 5 - 71.

Butte, W. and Heinzow, B. (2002). Pollutants in house dust as indicators of indoor contamination. Reviews of Environmental Contamination and Toxicology 175(1): 1.

Casteel, S.W., Weis, C.P., Henningsen, G.M. and Brattin, W.J. (2006). Estimation of relative bioavailability of lead in soil and soil-like materials using young swine. Environmental Health Perspectives 114(8): 1162 - 1171.

Chang, S.H., Wang, K.S., Chang, H.F., Ni, W.W., Wu, B.J., Wong, R.H. and Lee, H.S. (2009). Comparison of source identification of metals in road-dust and soil. Soil and Sediment Contamination: An International Journal 18(5): 669 - 683. DOI: https:// doi.org/10.1080/15320380903085691.

Charlesworth, S.M. and Lees, J.A. (1998). The distribution of heavy metals in deposited urban dusts and sediments, Coventry, England. Environmental Geochemistry and Health 21(2): 97 - 115.

Cooray, P.G. (1994). The precambrian of SL: a historical review. Precambrian Research 66(1 - 4): 3 - 18.

De Costa, W. (2008). Climate change in Sri Lanka: myth or reality? evidence from long-term meteorological data. Journal of the National Science Foundation of Sri Lanka 36(0): 63. DOI: https://doi.org/10.4038/jnsfsr. v36i0.8048.

Department of Census and Statistics (2012). Available from: http://www.statistics.gov.lk/PopHouSat/CPH2011/
Pages/Activities/Reports/FinalReport/FinalRepor.pdf ( 18 September 2020).

Department of Meteorology (2017). Available from: http:// www.meteo.gov.lk/index.php?option=comcontent\&vie $\mathrm{w}=$ article\&id=100\&Itemid=321\&lang=en\# (04 April. 2020).

Dissanayake, D.M.S.L.B., Morimoto, T., Ranagalage, M. and Murayama, Y. (2019). Land-use/land-cover changes and their impact on surface urban heat islands: case study of Kandy city, Sri Lanka. Climate 7(8): 99.

Furutani, H., Jung, J., Miura, K., Takami, A., Kato, S., Kajii, Y. and Uematsu, M. (2011). Single-particle chemical characterization and source apportionment of iron-containing atmospheric aerosols in Asian outflow. Journal of Geophysical Research: Atmospheres 116(D18): D18204. DOI: https://doi.org/ 10.1029/2011JD015867.

Garland, R.M., Yang, H., Schmid, O., Rose, D., Nowak, A., Achtert, P. and Kondo, Y. (2008). Aerosol optical properties in a rural environment near the megacity Guangzhou, China: implications for regional air pollution, radiative forcing and remote sensing. Atmospheric Chemistry and Physics 8(17): 5161 - 5186.

Gope, M., Masto, R.E., George, J., Hoque, R.R. and Balachandran, S. (2017). Bioavailability and health risk of some potentially toxic elements $(\mathrm{Cd}, \mathrm{Cu}, \mathrm{Pb}$, and $\mathrm{Zn}$ ) in street dust of Asansol, India. Ecotoxicology and Environmental Safety 138: 231 - 241. DOI: https://doi. org/10.1016/j.ecoenv.2017.01.008.

Gupta, V. (2020). Vehicle-generated heavy metal pollution in an urban environment and its distribution into various environmental components. In: Environmental Concerns and Sustainable Development 113-127, Springer, Singapore. DOI: https://doi.org/10.1007/978981-13-5889-0 5.

Guttikunda, S.K. and Goel, R. (2013). Health impacts of particulate pollution in a megacity-Delhi, India. Environmental Development 6: 8 - 20. DOI: https://doi.org/10.1016/j.envdev.2012.12.002.

Harrison, R.M. (2006). Composition, sources, and properties of airborne particulate matter. Epidemiology 17(6): 81.

Herath, D., Pitawala, A. and Gunatilake, J. (2015). A study on heavy metals in road deposited sediments and road dusts of Colombo capital, Sri Lanka. Journal of National Science Foundation Sri Lanka 44(2): 193 202.

Ibanez, Y., Le Bot, B. and Glorennec, P. (2010). House-dust metal content and bioaccessibility: a review. European Journal of Mineralogy 22(5): 629 - 637.

Kandy city transportation study (2011). Available from: https://kumarage.files.wordpress.com/2015/03/2011ucr-1-ut-kandy-city-transport-study-rda-123pp.pdf (18 September 2020).

Kantor, P., Svedova, B., Drozdová, J., Raclavská, H., Kucbel, M. and Raclavsky, K. (2018). Comparison of enrichment factors for heavy metals in urban street dust and air aerosols. Inżynieria Mineralna 19: 209 - 216. DOI: https://doi.org/10.29227/IM-2018-01-003. 
Kehelpannala, K.V.W. (2003). Structural evolution of the middle to lower crust in Sri Lanka -a review. Journal of Geological Society of Sri lanka 11: 45 - 85.

Kim, K.W., Myung, J.H., Ahn, J.S. and Chon, H.T. (1998). Heavy metal contamination in dusts and stream sediments in the Taejon area, Korea. Journal of Geochemical Exploration 64(1 - 3): 409 - 419. DOI: https://doi.org/10.1016/S0375-6742(98)00045-4.

Köllensperger, G., Friedbacher, G., Kotzick, R., Niessner, R. and Grasserbauer, M. (1999). In-situ atomic force microscopy investigation of aerosols exposed to different humidities. Fresenius' Journal of Analytical Chemistry 364(4): 296 - 304.

Li, X., Poon, C.S. and Liu, P.S. (2001). Heavy metal contamination of urban soils and street dust in Hong Kong. Applied Geochemistry 16(11 - 12): 1361 - 1368.

Ličbinský, R., Frýbort, A., Huzlík, J., Adamec, V., Effenberger, K., Mikuška, P. and Křůmal, K. (2010). Usage of scanning electron microscopy for particulate matter sources identification. Transactions on Transport Sciences 3(3): 137 - 144.

Mc Donald, R. and Biswas, P. (2004). A methodology to establish the morphology of ambient aerosols. Journal of the Air and Waste Management Association 54(9): 1069 - 1078. DOI: https://doi.org/10.1080/10473289.2 004.10470986.

McBride, M.B. (1994). Environmental Chemistry of Soils. Oxford University Press, Oxford.

Meza-Figueroa, D., González-Grijalva, B., Del Río-Salas, R., Coimbra, R., Ochoa-Landin, L. and MorenoRodríguez, V. (2016). Traffic signatures in suspended dust at pedestrian levels in semiarid zones: implications for human exposure. Atmospheric Environment 138: (2016) 4 - 14. DOI: https://doi.org/10/1016/j.atmoseenv. 2016.05.005.

Moreno, T., Martins, V., Querol, X., Jones, T., BéruBé, K., Minguillón, M.C. and Gibbons, W. (2015). A new look at inhalable metalliferous airborne particles on rail subway platforms. Science of The Total Environment 505: (2015) 367 - 375. DOI: https://doi. org/10/1016/j.scitotenv.2014.10.013.

Pereira, E., Baptista-Neto, J.A., Smith, B.J. and McAllister, J.J. (2007). The contribution of heavy metal pollution derived from highway runoff to Guanabara Bay sediments - Rio de Janeiro / Brazil. Anais Da Academia Brasileira de Ciencias 79(4): 739 - 750. DOI: https:// doi.org/10.1590/S0001-37652007000400013.

Pey, J., Rodríguez, S., Querol, X., Alastuey, A., Moreno, T., Putaud, J.P. and Van Dingenen, R. (2008). Variations of urban aerosols in the western Mediterranean. Atmospheric Environment 42(40): 9052 - 9062. DOI: https://doi.org/10.1016/j.atmosenv.2008.09.049.

Pitawala, A., Herath, D. and Piyatunga, N. (2013). Chemical characterization of household dust in two major cities: Colombo, the capital and Kandy, the hill capital, Sri Lanka. Carpathian Journal of Earth and Environmental Sciences 8(2): 89 - 95.

Pohl, J. and Emmermann, R. (1991). Chemical composition of the Sri Lanka Pricambrian basement. In: A. Kroner (Editor), The Crystalline Crust of Sri Lanka, Part I. Summary of Research of the German-Sri Lankan
Consortium. Geol. Surv. Dept. Sri Lanka, Prof. Pap. 5: $94-123$.

Pope III, C.A. and Dockery, D.W. (2006). Health effects of fine particulate air pollution: lines that connect. Journal of the Air and Waste Management Association 56(6): $709-742$.

Premasiri, H.D.S., Samarasinghe, I.H.K. and Lakmali, K.M.N. (2012). Population exposure risk assessment to air pollution in Kandy city area. $4^{\text {th }}$ Annual Proceedings of the National Building Research Organization Symposium, Ministry of Environment, Colombo. Pp. $182-187$.

Robertson, D.J., Taylor, K.G. and Hoon, S.R. (2003). Geochemical and mineral magnetic characterisation of urban sediment particulates, Manchester, UK. Applied Geochemistry 18(2): 269 - 282.

Rudnick, R.L. and Gao, S. (2003). Composition of the continental crust. Treatise on Geochemistry 3(2003): 659. DOI: https://doi.org/10.1016/B0-08-0437516/03016-4.

Shandilya, K.K., Khare, M. and Gupta, A.B. (2013). Organic matter determination for street dust in Delhi. Environmental Monitoring and Assessment 185(6): 5251 - 5264.

Shi, Y., Ji, Y., Sun, H., Hui, F., Hu, J., Wu, Y. and Lanza, M. (2015). Nanoscale characterization of PM 2.5 airborne pollutants reveals high adhesiveness and aggregation capability of soot particles. Scientific Reports 5: 11232. DOI: https://doi.org/10.1038/srep11232.

Shilton, V.F., Booth, C.A., Smith, J.P., Giess, P., Mitchell, D.J. and Williams, C.D. (2005). Magnetic properties of urban street dust and their relationship with organic matter content in the West Midlands, UK. Atmospheric Environment 39(20): 3651 - 3659.

Spassov, S., Egli, R., Heller, F., Nourgaliev, D.K. and Hannam, J. (2004). Magnetic quantification of urban pollution sources in atmospheric particulate matter. Geophysical Journal International 159(2): 555 - 564.

Tüzen, M. (2003). Determination of heavy metals in soil, mushroom, and plant samples by atomic absorption spectrometry. Microchemical Journal 74(3): 289 - 297.

Wang, C.F., Chang, C.Y., Tsai, S.F. and Chiang, H.L. (2005). Characteristics of road dust from different sampling sites in northern taiwan. Journal of the Air and Waste Management Association 55(8): 1236 1244. DOI: https://doi.org/10.1080/10473289.2005.10 464717.

Wang, J., Li, S., Cui, X., Li, H., Qian, X., Wang, C. and Sun, Y. (2016). Bioaccessibility, sources and health risk assessment of trace metals in urban park dust in Nanjing, Southeast China. Ecotoxicology and Environmental Safety 128: 161 - 170. DOI: https://doi.org/10.1016/j. ecoenv.2016.02.020.

Wang, Y., Hopke, P.K., Chalupa, D.C. and Utell, M.J. (2011). Long-term study of urban ultrafine particles and other pollutants. Atmospheric Environment 45(40): 7672 - 7680. DOI: https://doi.org/10.1016/j. atmosenv.2010.08.022. 
Weerasundara, L., Amarasekara, R.W.K., MaganaArachchi, D.N., Ziyath, A.M., Karunaratne, D.G.G.P., Goonetilleke, A. and Vithanage, M. (2017). Microorganisms and heavy metals associated with atmospheric deposition in a congested urban environment of a developing country: Sri Lanka. Science of the Total Environment 584 - 585: 803 - 812. DOI: https://doi.org/10.1016/j.scitotenv.2017.01.121.

Xie, S., Dearing, J.A. and Bloemendal, J. (2000). The organic matter content of street dust in Liverpool, UK, and its association with dust magnetic properties. Atmospheric Environment 34(2): 269 - 275.

Yang, Y., Liu, L., Xiong, Y., Zhang, G., Wen, H., Lei, J. and Lyu, Y. (2016). A comparative study on physicochemical characteristics of household dust from a metropolitan city and a remote village in China. Atmospheric Pollution Research 7(6): 1090 - 1100. 